\title{
Hubungan Pertumbuhan Varietas Sagu (Metroxylon sago Rottb) dengan Faktor Lingkungan di Desa Seget Papua Barat
}

\author{
Relationships between Growth of Sago Variety (Metroxylon sago Rottb) with Environmental \\ Factors in Seget Village West Papua
}

\section{Batseba Alfonsina Suripatty}

\author{
Balai Penelitian dan Pengembangan Lingkungan Hidup dan Kehutanan Manokwari \\ Telp. (0986)-213437 / 213440. Fax. (0986)-213441 / 213437 \\ Penulis Korespondensi: E-mail: bettysuripatty@gmail.com
}

\begin{abstract}
A good environment for sago plants is muddy, mineral-rich and organic material, brown groundwater and slightly acidic. Sago lives in the form of clumps, where in one clump there are various growth rates ranging from young plants to fruiting. The optimal amount of rainfall for growth between 2000-4000 mm/year, which is spread evenly throughout the year. This study aims to have inventory and to know the relationship between sago growth factors. Sago inventory results obtained 4 varieties namely Metroxylon sago Rottb var. wahna, M. sago Rottb var. wamda, M. sago Rottb var. wirere and M. sago Rottb var. wafok. The relationships between growth and environmental factors such as soil porosity, water pH, moisture, light, and vegetation produced that in general water has an influence on growth while the humidity factor for all types of places of growth i.e in the flooded areas, temporary areas and dry areas does not affect growth.
\end{abstract}

Keywords: environmental factor, inventory, sago variety, Seget

\section{ABSTRAK}

Lingkungan yang baik untuk tumbuhan sagu adalah daerah yang berlumpur, kaya mineral dan bahan organik, air tanah berwarna coklat dan bersifat agak asam. Sagu hidup dalam bentuk rumpun, dimana dalam satu rumpun terdapat berbagai tingkat pertumbuhan mulai dari tumbuhan muda sampai berbuah. Jumlah curah hujan yang optimal bagi pertumbuhan antara 2.000-4.000 mm/tahun, yang tersebar merata sepanjang tahun. Penelitian ini bertujuan untuk menginventarisasi dan mengetahui hubungan faktor-faktor pertumbuhan sagu. Hasil inventarisasi sagu diperoleh 4 varietas yaitu Metroxylon sago Rottb varietas wahna, $M$. sago Rottb varietas wamda, $M$. sago Rottb varietas wirere dan M. sago Rottb varietas wafok. Hubungan pertumbuhan dengan faktor lingkungan porositas tanah, $\mathrm{pH}$ air, kelembapan, cahaya, dan vegetasi dihasilkan bahwa secara umum air mempunyai pengaruh terhadap pertumbuhan sedangkan faktor kelembaban untuk semua tipe tempat tumbuh yakni pada daerah tergenang, daerah temporer dan daerah kering tidak mempengaruhi pertumbuhan.

Kata kunci: faktor lingkungan, inventory, Seget, varietas sagu

\section{PENDAHULUAN}

Papua merupakan salah satu pulau di Indonesia yang memiliki kekayaan yang melimpah. Luas hutan di Papua mencapai 1.406.469 ha, atau sekitar 90\% dari luas total hutan di Indonesia (Jong dan Widjono, 2007). Sekitar $30 \%$ penduduk Papua mengkonsumsi sagu sebagai makanan pokoknya (Barahima, 2006). Disatu sisi sagu juga merupakan bahan makanan pengganti jika ubi-ubian tidak memenuhi kebutuhan pada daerah tertentu (Wahid, 1988). Selanjutnya jika ditinjau dari segi penghasil karbohidrat, tumbuhan sagu memiliki kemampuan untuk menghasilkan karbohidrat lebih tinggi dibandingkan dengan tanaman penghasil kabohidrat lainnya seperti yang di jelaskan oleh Bantacut (2016) bahwa tepung beras $90,69 \%$ karbohidrat, tepung terigu $87,84 \%$ karbohidrat, ubi kayu 94,75\% karbohidrat, jagung 83,68\% karbohidrat, ubi jalar 68,5\% karbohidrat, kentang 93,61\% karbohidrat dan sagu 100\% karbohidrat. Selain itu, sagu juga mengandung kadar abu $0,27 \%$, protein $0,75 \%$, lemak $0.42 \%$ dan amilosa $33,1 \%$ (Polnaya et al., 2012)

Lingkungan yang baik untuk tumbuhan sagu adalah daerah yang berlumpur, kaya mineral dan bahan organik, air tanah berwarna coklat dan bersifat agak asam (Flach, 1977). Sagu hidup dalam bentuk rumpun, dimana dalam satu rumpun terdapat berbagai tingkat pertumbuhan mulai dari tumbuhan muda sampai berbuah. Jumlah curah hujan yang optimal bagi pertumbuhan antara 2.000-4.000 $\mathrm{mm} /$ tahun, yang 
tersebar merata sepanjang tahun. Secara ekologi lahan dapat melindungi air tanah, menyimpan dan memberikan air pada habitatnya.

Studi tentang tumbuhan sagu di propinsi Papua Barat selama ini telah dilakukan oleh para peneliti, namun ketersediaan data tentang ekologi dari jenis di hutan alam Papua Barat terutama di Seget belum tersedia. Untuk itu penelitian tentang identifikasi jenis dan hubungan faktor pertumbuhan akan memberikan kontribusi atau sebagai sumber data bagi pemerintah Daerah dan stakeholder yang akan melakukan penelitian selanjutnya. Penelitian ini bertujuan untuk menginventarisasi dan mengetahui hubungan faktorfaktor pertumbuhan sagu.

\section{METODOLOGI PENELITIAN}

\section{Inventarisasi Varietas Sagu}

Kondisi populasi tumbuhan pada lokasi penelitian tersebar secara merata dan berkelompok, untuk itu pengambilan data kelimpahan dan sebaran pada lokasi penelitian Seget dibuat jalur rintis sepanjang $500 \mathrm{~m}$, dan pada petak contoh (petak pengamatan) ukuran $20 \mathrm{~m} \times 20$ $\mathrm{m}$, sehingga jumlah petak ukur dalam setiap jalur sebanyak 25, dan jarak antar jalur $200 \mathrm{~m}$, jumlah jalur pengamatan sebanyak 10 jalur sehingga total petak ukur untuk setiap lokasi penelitian adalah 250. Petak Ukur (PU) diletakkan di sepanjang jalur mulai dari pohon yang ada dengan arah tegak lurus sungai, petak pengamatan.

Teknik penarikan contoh yang dibuat pada penentuan plot awal menggunakan random sampling, kemudian penentuan plot selanjutnya menggunakan systematic plot sampling. Luas Hutan Distrik Seget adalah 862,82 Ha maka Intensitas Sampling ( IS) yang pakai di hutan alam Seget adalah 2,32\%.

\section{Pengamatan Faktor Lingkungan}

\section{Edafik}

Sampel tanah untuk pengujian sifat fisika dan kimia tanah diambil di sepanjang plot pengamatan. Sampel sifat kimia tanah diambil dari sampel tanah komposit, sedangkan sifat fisik tanah sampelnya diperoleh dari tanah padat dengan menggunakan ring sampel pada kedalaman tanah $15 \mathrm{~cm}$ dari permukaan tanah. Analisis sifat fisik dan kimia tanah dilakukan dengan menggunakan metode berikut: Sampel tanah yang diambil dipisahkan menurut tipe habitat. Sifat-sifat tanah yang diamati meliputi sifat fisika dan kimia tanah. Terdapat sifat tanah yang ditentukan langsung di lapangan seperti $\mathrm{pH}$ tanah, sedangkan sifat tanah yang lain ditetapkan di laboratorium. Pengambilan sampel tanah untuk keperluan analisis kimia tanah dilakukan pada kedalaman 0-30 $\mathrm{cm}$ dan 30-60 cm. Penetapan kedalaman ini didasarkan pada hasil observasi pendahuluan, dimana didapatkan akumulasi sebaran perakaran berada pada zone kedalaman 0-60 cm. Sampel tanah untuk keperluan analisis sifat fisika tanah menggunakan ring sampel pada kedalaman antara 0-30 $\mathrm{cm}$ (top soil).

\section{Sifat-Sifat Tanah}

\section{Sifat Fisik Tanah}

Pada setiap wilayah sampel diambil tiga sampel untuk setiap zona habitat yaitu kering, temporer dan rawa. Dengan demikian jumlah sampel yang digunakan untuk keperluan analisis untuk dua lokasi penelitian adalah sebanyak: $3 \times 3 \times 2=18$ sampel. Sifat fisika tanah yang diamati dalam penelitian ini meliputi bulk density dan porositas. Analisisnya dilakukan di laboratorium departemen Ilmu Tanah dan Sumberdaya Lahan Fakultas Pertanian IPB Bogor.

\section{Sifat Kimia Tanah}

Sampel tanah untuk keperluan analisis sifat kimia tanah dari tipe habitat yang sama dikompositkan, kemudian dari komposit tersebut diambil sebanyak tiga sampel untuk setiap tipe habitat. Dengan demikian jumlah sampel secara keseluruhan dari dua lokasi jumlahnya sebanyak: $3 \times 3 \times 2=18$ sampel. Sifat-sifat tanah yang dianalisis adalah: 1) $\mathrm{pH}$, ditetapkan dengan menggunakan $\mathrm{pH}$ meter tanah, penetapannya dilakukan langsung di lapangan sampai ketemu tanah dengan menggunakan bor tanah untuk mengetahui kedalaman tanah. Hasil pengukuran ini kemudian dibandingkan dengan hasil pengukuran di laboratorium Selain $\mathrm{pH}$ $\left(\mathrm{H}_{2} \mathrm{O}\right)$ dilakukan pula penetapan $\mathrm{pH}(\mathrm{KCl})$ untuk mengetahui $\mathrm{pH}$ potensial di lokasi penelitian. Penetapan $\mathrm{pH}(\mathrm{KCl})$ dilakukan di laboratorium; dan 2) Sampel bahan organik yang diambil adalah lapisan atas tanah C-organik. Analisis sifat kimia tanah dilakukan di laboratorium Seameo Biotrop Services Laboratory Bogor.

Tabel 1. Metodologi dalam analisis sifat fisik dan kimia tanah

\begin{tabular}{cll}
\hline \multicolumn{2}{c}{ Sifat Tanah } & \multicolumn{1}{c}{ Metodologi } \\
\hline Fisik & & \\
- & Porositas & Ring Sampel \\
- & Bulk Density & Ring Sampel \\
Kimia & pH Meter \\
$-\quad$ pH & Wet or dry combustion, \\
- & C-organik & volumetric basis \\
- & N-total & Wet or dry combustion, \\
- & Bahan organik & volumetric basis \\
& & \\
& &
\end{tabular}

\section{Sifat air}

Sampel air diambil dari zona habitat tergenang, yaitu tergenang temporer air tawar (TT), dan tergenang permanen (TP). Sampel air diambil secara hati-hati dari bagian permukaan, bagian tengah, dan bagian bawah dan dicatat per ketinggian. Pada setiap zona sampel diambil tiga sampel secara diagonal, sama seperti pengambilan sampel tanah. Sampel dari zona habitat yang sama 
kemudian dicampur untuk selanjutnya diambil tiga sampel pada setiap tipe habitat. Dengan demikian, maka jumlah sampel secara keseluruhan dari dua wilayah sampel, dua tipe habitat, dan tiga sampel dari masingmasing habitat adalah sebanyak $2 \times 2 \times 3=12$ sampel air.

Pengukuran variabel yang berkaitan dengan sifat air sebagian dilakukan di lapangan dan sebagian di laboratorium. Sifat-sifat air yang diamati yaitu: a) $\mathrm{pH}$, ditetapkan dengan menggunakan $\mathrm{pH}$ meter air; dan b) salinitas, ditetapkan dengan menggunakan salinitas meter atau refraktometer.

Analisis sifat air dilakukan di laboratorium penguji Balai Pengkajian Bioteknolgi Badan Pengkajian dan Penerapan Teknologi (BPPT) Serpong.

\section{Klimatik}

\section{Iklim}

Data yang dikumpulkan adalah temperatur udara, dan kelembaban udara relatif, curah hujan, hari hujan, rata-rata suhu udara maksimum dan minimum, dikumpulkan di kantor BMKG kota Sorong Data iklim lokal ini diperoleh dari dua stasiun Klimatologi yaitu stasiun Klimatologi Sorong. Semua data yang meliputi parameter iklim, tanah, dan kualitas air rawa yang berasal dari dua wilayah sampel yaitu wilayah sampel Seget Kabupaten Sorong, selanjutnya dikompilasi untuk memperoleh data rataan. Data rataan inilah yang dipergunakan untuk menjelaskan menganai kondisi iklim (terutama iklim mikro), tanah, dan kualitas air rawa dalam komunitas alami di Papua Barat.

\section{Analisis Data}

\section{Sebaran Jenis (Metroxylon sago Rottb )}

Untuk mengetahui pola distribusi spasial jenis , digunakan alat penyelesaian statistik Indeks Dispersi (ID) dengan rumus:

$$
\text { Indeks Dispersi (ID) }=\frac{s^{2}}{\overline{\mathrm{X}}}
$$

Keterangan :

$\frac{\mathrm{ID}}{\mathrm{X}}=$ Indeks Dispersi; $S^{2}=$ Varian, $\overline{\mathrm{X}}=$ rata-rata jumlah species.

Nilai Indeks Dispersi (ID) akan diperoleh apabila nilai varians $\left(\mathrm{S}^{2}\right)$ telah diketahui dan nilai varians $\left(\mathrm{S}^{2}\right)$ akan diperoleh apabila nilai Chi-square $\left(X^{2}\right)$ telah diketahui. Menurut Ludwig dan Reynold (1988), nilai varians $\left(S^{2}\right)$, dapat dihitung menggunakan rumus:

$$
\mathrm{S}^{2}=\frac{\left[\sum(\mathrm{XFX})^{2}-\mathrm{X}_{\text {rata-rata }} \cdot \mathrm{n}\right]}{\mathrm{N}-1}
$$

Keterangan: $X=$ jumlah individu pada setiap unit sampling (US); FX = frekuensi dari setiap US yang memiliki individu sejumlah $\mathrm{X} ; \overline{\mathrm{X}}=$ rata-rata jumlah individ; dan $\mathrm{n}=$ Jumlah individu suatu jenis pada setiap petak ukur.

Nilai Chi-square $\left(\chi^{2}\right)$ dihitung menggunakan rumus:

$$
\chi^{2}=\frac{\left[\sum_{\mathrm{i}=\mathrm{n}}^{\mathrm{N}}\left(\mathrm{X}_{\mathrm{i}}-\mathrm{X}_{\text {rata-rata }}\right)^{2}\right]}{\mathrm{X}_{\text {rata-rta }}}=\text { ID (N-1) }
$$

Keterangan: $X_{i}=$ Jumlah individu pada waktu jenis ke- $i$ di US; N = Jumlah total US; dan ID = Indeks disperse.

Menurut Poedjirahajoe (2009), Ludwig dan Reynold (1988) dan Krebs (1989) menyebutkan bahwa dari hasil perhitungan di atas terdapat ketentuan poisson, yaitu: a) Suatu jenis tumbuhan dikategorikan mempunyai pola sebaran mengelompok apabila mempunyai nilai $\chi^{2}$ hitung lebih dari nilai tabel $\chi^{2} 0,025\left(\chi^{2}\right.$ hit $\left.>0,025\right)$; b) Suatu jenis tumbuhan dikategorikan mempunyai pola sebaran acak, apabila mempunyai nilai $\chi^{2}$ hitung berada pada nilai tabel $\chi^{2} \quad 0,975$ hingga nilai tabel $\chi^{2} \quad 0,025$ $\left(0,025>\chi_{\text {hit }}^{2}>0,975\right)$; dan c) Suatu jenis tumbuhan dikategorikan mempunyai pola sebaran seragam, apabila mempunyai nilai $\chi^{2}$ hitung kurang dari nilai tabel $\chi^{2}$ $0,975\left(\chi_{\text {hit }}^{2}<0,975\right)$.

Menurut Krebs (1989), ketentuan di atas berlaku untuk jumlah pengambilan sampel kurang dari 51 (n < 51) dan apabila sampel (petak ukur) lebih dari 51 (n > 51) maka digunakan penaksiran normal untuk nilai $C h i$ square $\left(\chi^{2}\right)$ dengan uji $\mathrm{Z}$, menggunakan rumus:

$$
Z=\sqrt{2} X^{2}-\sqrt{2 v-1}
$$

Keterangan: $\mathrm{Z}=$ standart normal deviasi $(\mu=0 ; \alpha=1) ; \chi^{2}$ $=$ nilai Chi-square; dan $\mathrm{V}=$ derajat bebas (n-1).

Dari hasil perhitungan uji $\mathrm{Z}$ untuk pola sebaran pada nilai $\alpha=0,05$ berlaku ketentuan: bahwa pola acak apabila nilai $\mathrm{Z}$ berkisar antara $-1,96$ hingga 1,96; pola mengelompok apabila nilai $\mathrm{Z}$ lebih dari 1,96 dan pola seragam apabila nilai Z kurang dari -1,96.

\section{Hubungan Pertumbuhan dengan Faktor Lingkungan porositas tanah, pH air, kelembaban, Cahaya, dan Vegetasi}

\section{Koefisien Determinasi $\left(R^{2}\right)$}

Koefisien determinasi digunakan untuk mengetahui seberapa besar hubungan dari beberapa variabel dalam pengertian yang lebih jelas. Koefisien determinasi akan menjelaskan seberapa besar perubahan atau variasi suatu variabel bisa dijelaskan oleh perubahan atau variasi pada variabel yang lain. Nilai $R^{2}$ berada pada interval $0<R^{2}<1$.

Nilai $R^{2}$ dapat diperoleh dengan rumus:

$$
R^{2}=(r)^{2} \times 100 \%
$$

Dimana: $R^{2}=$ koefisien determinasi, $r=$ koefisien korelasi.

Nilai koefisien ini antara 0 dan 1 , jika hasil lebih mendekati angka 0 berarti kemampuan variabel-variabel independen dalam menjelaskan variasi variabel amat terbatas. Tapi jika hasil mendekati angka 1 berarti variabel-variabel independen memberikan hampir semua informasi yang dibutuhkan untuk memprediksi variasivariabel dependent.

\section{Uji t}

Uji $t$ digunakan untuk menguji berarti atau tidaknya hubungan variabel independen, dengan variabel dependen dengan pengambilan keputusan sebagai 
berikut: a) nilai $t_{\text {hitung }}\left\langle t_{\text {tabel }}\right.$ atau signifikasi $(P$ Value $\left.)\right\rangle$ 0,05 artinya tidak ada hubungan antara variabel independen dengan variabel dependen; b) nilai $t_{\text {hitung }}>$ $t_{\text {tabel }}$ atau signifikasi $(P$ Value $)<0,05$ ada hubungan antara variabel independen dengan variable dependen; dan c) suatu jenis tumbuhan dikategorikan mempunyai pola sebaran seragam, apabila mempunyai nilai $\chi^{2}$ hitung kurang dari nilai tabel $\chi^{2} 0,975\left(\chi^{2}\right.$ hit $\left.<0,975\right)$.

\section{Analisis Regresi Linier Berganda}

Penelitian ini menggunakan analisis regresi berganda karena jumlah variabel independen yang digunakan lebih dari satu variabel antara lain porositas tanah, pH air, kelembaban, cahaya dan vegetasi sedangkan variabel dependen adalah pertumbuhan tegakan. Menurut Sugiyono (2005), perumusan dari regresi linier berganda adalah sebagai berikut :

$$
Y=a+b_{1} X_{1}+b_{2} X_{2}+b_{3} X_{3}+b_{4} X_{4}+b_{5} X_{5}+E
$$

Keterangan: $Y=$ Pertumbuhan tegakan; $a=$ konstanta; $b_{1}$ $=$ Koefisien regresi variabel $X_{1}$ (Porositas tanah); $b_{2}=$ Koefisien regresi variabel $X_{2}\left(\mathrm{pH}\right.$ Air); $b_{3}=$ Koefisien regresi variabel $X_{3}$ (Kelembaban); $b_{4}=$ Koefisien regresi variabel $X_{4}$ (Cahaya); $b_{5}=$ Koefisien regresi variabel $X_{5}$ (Vegetasi); $\mathrm{E}=$ error.

\section{HASIL DAN PEMBAHASAN}

\section{Sebaran Sagu (M. sagu Rottb) di Hutan Alam Seget}

Jenis-jenis sagu (M. sago Rottb) yang ditemukan di lokasi penelitian yaitu hutan alam Seget antara lain: $M$. sago Rottb varietas wahna; $M$. sagu Rottb varietas wamda; $M$. sagu Rottb varietas wirere; dan $M$. sago Rottb varietas wafok.

\section{Distribusi Spasial}

Hasil analisis sebaran $M$. sago Rottb dilokasi penelitian Seget seperti pada Tabel 2 menunjukkan bahwa hasil sebaran yang tidak berbeda jauh yakni nilai $\chi^{2}$ hitung. Hasil analisis di atas menunjukkan bahwa sebaran di lokasi penelitian Seget dikategorikan dalam pola sebaran mengelompok, hal ini diperjelas oleh Poedjirahajoe (2009), Ludwig dan Renold (1988) dan Krebs (1989) bahwa hasil perhitungan dengan menggunakan indeks dispersi mempunyai ketentuan Poisson yaitu suatu jenis tumbuhan dikategorikan mempunyai pola sebaran mengelompok apabila mempunyai nilai $\chi^{2}$ hitung lebih dari nilai tabel $\chi^{2} 0,025$ $\left(\chi_{\text {hit }}^{2}>0,025\right)$.

\section{Hubungan pertumbuhann ( $M$. sagu Rottb) dengan porositas tanah, pH air, kelembaban, cahaya, dan jumlah vegetasi terhadap pertumbuhan pada masing- masing varietas tumbuhan}

Berdasarkan Tabel 3, terlihat bahwa variabel yang mempengaruhi pertumbuhan adalah porositas tanah, air, cahaya, dan vegetasi. Menurut Harsanto (1985) menyatakan bahwa tempat tumbuh yang baik bagi tanaman adalah pada tanah yang tidak tergenang air sehingga akar napas tidak terendam. Tempat tumbuh demikian tidak ditemui di daerah rawa dan transisi. Kondisi drainase yang jelek dihambat oleh permukaan air tanah yang tinggi, mengakibatkan ruang pori tanah seluruhnya terisi air.

Daerah temporer pada lokasi pengamatan memiliki kadar karbon tergolong sangat tinggi yaitu $14,021 \%$, daerah rawa tergolong tinggi dan daerah kering tergolong sedang. Keadaan kadar karbon tersebut didukung oleh pernyataan yang dikemukakan oleh Fitter dan Hay (1992) yang menyatakan bahwa sifat tidak mendukung dari tanah tergenang pada daerah temporer dan daerah rawa adalah konsentrasi karbon yang tinggi dan keadaan oksigen yang rendah, sehingga mengakibatkan terhambatnya perkembangan dan penyebaran akar di dalam tanah.

Daerah kering pada lokasi pengamatan memiliki kadar nitrogen yaitu 0,0636\% tergolong sangat rendah, daerah rawa tergolong rendah yaitu $0,1999 \%$ dan daerah temporer tergolong tinggi dengan nilai $0,6356 \%$. Namun dengan adanya keadaan tanah yang tergenang, drainase yang buruk dan tata udara yang jelek pada daerah temporer dan daerah rawa menyebabkan terciptanya situasi anaerobik sehingga organisme tanah akan menggunakan nitrat dan mereduksinya menjadi gas nitrogen, mengakibatkan nitrogen berubah bentuk yang tidak tersedia bagi tumbuhan (Hardjowigeno, 1987).

Faktor lingkungan yaitu air, cahaya dan vegetasi mempengaruhi pertumbuhan varietas Wafok, pada daerah tergenang, daerah temporer dan daerah kering, sedangkan kelembaban tidak mempengaruhi pertumbuhan. Untuk varietas Wahna, air dan cahaya mempengaruhi pertumbuhan pada daerah tergenang dan temporer sedangkan kelembaban dan vegetasi tidak mempengaruhi. Untuk varietas Wahna pada daerah kering air dan vegetasi mempengaruhi pertumbuhan, sedangkan kelembaban dan cahaya tidak mempengaruhi. Untuk varietas Wirere pada daerah tergenang dan daerah temporer, air dan cahaya mempengaruhi pertumbuhan, sedangkan kelembaban dan vegetasi tidak mempengaruhi.

Tabel 2. Sebaran (Metroxylon sago Rottb ) di lokasi penelitian Seget

\begin{tabular}{lcccc}
\hline \multicolumn{1}{c}{ Jenis } & Varians & X-hitung & $\begin{array}{c}\text { X-tabel } \\
(\mathbf{0 , 0 2 5})\end{array}$ & ID \\
\hline M. sagu Rottb varietas Wafok & 259,8077 & 137,8571 & 34,7 & 10,6044 \\
M. sagu Rottb varietas Wahnan & 214,8846 & 169,3030 & 34,7 & 13,0233 \\
M. sagu Rottb varietas Wamda & 643,7198 & 101,7871 & 34,7 & 7,8298 \\
M. sagu Rottb varietas Wirere & 68,2472 & 102,6529 & 34,7 & 7,8964 \\
\hline
\end{tabular}


Tabel 3. Hubungan pertumbuhan (Metroxylon sago Rottb) dengan porositas tanah, pH air, kelembaban, cahaya, dan jumlah vegetasi terhadap pertumbuhan pada masing-masing varietas tumbuhan

\begin{tabular}{|c|c|c|c|}
\hline Areal & Varietas & Regresi & Nilai R \\
\hline \multirow{8}{*}{ Rawa } & M. sagu varietas & $-15,994+0,128$ Porositas Tanah $+1,145 \mathrm{pH}$ air $+0,154$ Kelembaban + & \\
\hline & Wafok & 0,106 Cahaya - 0,099 Vegetasi & \\
\hline & M. sagu varietas & $-15,002+0,177$ Porositas Tanah $+1,584 \mathrm{pH}$ air $+0,057$ Kelembaban + & \\
\hline & Wahna & 0,123 Cahaya - 0,053 Vegetasi & \\
\hline & M. sagu varietas & $-0,913+0,093$ Porositas Tanah $+1,347 \mathrm{pH}$ air $+0,025$ Kelembaban + & \\
\hline & Wamda & 0,042 Cahaya - 0,052 Vegetasi & \\
\hline & M. sagu varietas & $-11,674+0,090$ Porositas Tanah $+1,438 \mathrm{pH}$ a & \\
\hline & Wirere & 0,055 Cahaya - 0,046 Vegetasi & \\
\hline \multirow{6}{*}{$\begin{array}{l}\text { Tempor } \\
\text { er }\end{array}$} & M. sagu varietas & $-21,960+0,091$ Porositas Tanah $+1,799 \mathrm{pH}$ air $+0,172$ Kelembaban + & \\
\hline & Wafok & 0,127 Cahaya - 0,106 Vegetasi & \\
\hline & $\begin{array}{l}\text { M. ssagu varietas } \\
\text { Vahna }\end{array}$ & $\begin{array}{l}-18,800+0,173 \text { Porositas Tanah }+2,088 \mathrm{pH} \text { air }+0,059 \text { Kelembaban }+ \\
0,094 \text { Cahava }-0,105 \text { Vegetasi }\end{array}$ & \\
\hline & M. sagu varietas & $-10,747+0,074$ Porositas Tanah $+1,759$ & 0,817 \\
\hline & Wamda & 0,037 Cahaya - 0,082 Vegetasi & \\
\hline & $\begin{array}{l}\text { M. sagu varietas } \\
\text { Wirere }\end{array}$ & $\begin{array}{l}-17,873+0,081 \text { Porositas Tanah }+1,669 \mathrm{pH} \text { air }+0,151 \text { Kelembaban }+ \\
0,067 \text { Cahaya }-0,074 \text { Vegetasi }\end{array}$ & 0,775 \\
\hline \multirow{4}{*}{ Kering } & $\begin{array}{l}\text { M. sagu varietas } \\
\text { Wafok }\end{array}$ & $\begin{array}{l}-15,402+0,148 \text { Porositas Tanah }+1,353 \mathrm{pH} \text { air }+0,183 \text { Kelembaban }+ \\
0,051 \text { Cahaya }-0,132 \text { Vegetasi }\end{array}$ & 0,767 \\
\hline & $\begin{array}{l}\text { M. sagu varietas } \\
\text { Wahna }\end{array}$ & $\begin{array}{l}-21,459+0,217 \text { Porositas Tanah }+1,375 \mathrm{pH} \text { air }+0,180 \text { Kelembaban }+ \\
0,074 \text { Cahaya }-0,114 \text { Vegetasi }\end{array}$ & 0,720 \\
\hline & $\begin{array}{l}\text { M. sagu varietas } \\
\text { Wamda }\end{array}$ & $\begin{array}{l}-9,830+0,081 \text { Porositas Tanah }+1,420 \mathrm{pH} \text { air }+0,169 \text { Kelembaban }+ \\
0,027 \text { Cahaya }-0,122 \text { Vegetasi }\end{array}$ & 0,848 \\
\hline & $\begin{array}{l}\text { M. sagu varietas } \\
\text { Wirere }\end{array}$ & $\begin{array}{l}15,913+0,105 \text { Porositas Tanah }+1,405 \mathrm{pH} \text { air }+0,204 \text { Kelembaban }+ \\
0,028 \text { Cahaya }-0,090 \text { Vegetasi }\end{array}$ & 0,806 \\
\hline
\end{tabular}

Faktor lingkungan yaitu air, cahaya dan vegetasi mempengaruhi pertumbuhan varietas Wafok, pada daerah tergenang, daerah temporer dan daerah kering, sedangkan kelembaban tidak mempengaruhi pertumbuhan. Untuk varietas Wahna, air dan cahaya mempengaruhi pertumbuhan pada daerah tergenang dan temporer sedangkan kelembaban dan vegetasi tidak mempengaruhi. Untuk varietas Wahna pada daerah kering air dan vegetasi mempengaruhi pertumbuhan, sedangkan kelembaban dan cahaya tidak mempengaruhi. Untuk varietas Wirere pada daerah tergenang dan daerah temporer, air dan cahaya mempengaruhi pertumbuhan, sedangkan kelembaban dan vegetasi tidak mempengaruhi.

\section{Koefisien Determinasi pengaruh faktor lingkungan porositas tanah, pH air, kelembaban, cahaya, dan vegetasi terhadap pertumbuhan}

Koefisien Determinasi pengaruh faktor lingkungan porositas tanah, $\mathrm{pH}$ air, kelembaban, cahaya dan vegetasi terhadap pertumbuhan, seperti pada Tabel 4.

Hasil analisis yang ditunjukkan pada Tabel 4 menjelaskan bahwa besarnya koefisien determinasi pada lokasi penelitian diperoleh nilai terendah adalah 0,653 tanah tergenang untuk sagu varietas Wafok dan tertinggi pada tanah kering sebesar 0,848 untuk sagu varietas Wamda.
Tabel 4. Koefisien determinasi pengaruh faktor lingkungan $\mathrm{pH}$ tanah, $\mathrm{pH}$ air, kelembaban, cahaya, dan vegetasi terhadap pertumbuhan di Seget

\begin{tabular}{|c|c|c|}
\hline Areal & Varietas & R Square \\
\hline \multirow{4}{*}{ Tanah Rawa } & $\begin{array}{l}\text { Metroxylon sagu Rottb } \\
\text { varietas Wafok }\end{array}$ & 0,653 \\
\hline & $\begin{array}{l}\text { M. sagu Rottb varietas } \\
\text { Wahnan }\end{array}$ & 0,654 \\
\hline & $\begin{array}{l}\text { M. sagu Rottb varietas } \\
\text { Wamda }\end{array}$ & 0,757 \\
\hline & $\begin{array}{l}\text { M. sagu Rottb varietas } \\
\text { Wirere }\end{array}$ & 0,730 \\
\hline \multirow{4}{*}{$\begin{array}{c}\text { Tanah } \\
\text { Temporer }\end{array}$} & $\begin{array}{l}\text { M. sagu Rottb varietas } \\
\text { Wafok }\end{array}$ & 0,726 \\
\hline & $\begin{array}{l}\text { M. sagu Rottb varietas } \\
\text { Wahnan }\end{array}$ & 0,715 \\
\hline & $\begin{array}{l}\text { M. sagu Rottb varietas } \\
\text { Wamda }\end{array}$ & 0,817 \\
\hline & $\begin{array}{l}\text { M. sagu Rottb varietas } \\
\text { Wirere }\end{array}$ & 0,775 \\
\hline \multirow{4}{*}{$\begin{array}{l}\text { Tanah } \\
\text { Kering }\end{array}$} & $\begin{array}{l}\text { M. sagu Rottb varietas } \\
\text { Wafok }\end{array}$ & 0,767 \\
\hline & $\begin{array}{l}\text { M. sagu Rottb varietas } \\
\text { Wahnan }\end{array}$ & 0,720 \\
\hline & $\begin{array}{l}\text { M. sagu Rottb varietas } \\
\text { Wamda }\end{array}$ & 0,848 \\
\hline & $\begin{array}{l}\text { M. sagu Rottb varietas } \\
\text { Wirere }\end{array}$ & 0,806 \\
\hline
\end{tabular}


Rata-rata koefisien determinasi untuk lokasi penelitian Seget, dan pada tanah yaitu pengaruh porositas tanah, air, kelembaban, cahaya, dan vegetasi terhadap pertumbuhan sebesar $71,4 \%$. Sedangkan sisanya $28,6 \%$ dipengaruhi oleh faktor-faktor lainnya.

\section{KESIMPULAN}

1. Komposisi (M. sagu Rottb) di hutan alam Seget ditemukan empat varietas sagu. Sebaran varietas sagu yang ditemukan yaitu secara berkelompok di hutan alam. Komposisi varietas sagu yang ditemukan pada lokasi penelitian yaitu $M$. sagu Rottb varietas wahna, M. sagu Rottb varietas wamda, M. sagu Rottb varietas wirere dan $M$. sagu Rottb varietas wafok.

2. Hubungan pertumbuhan dengan faktor lingkungan porositas tanah, $\mathrm{pH}$ air, kelembapan, cahaya, dan vegetasi dihasilkan bahwa secara umum air mempunyai pengaruh terhadap pertumbuhan sedangkan faktor kelembaban untuk semua tipe tempat tumbuh yakni pada daerah tergenang, daerah temporer dan daerah kering tidak mempengaruhi pertumbuhan.

\section{DAFTAR PUSTAKA}

Barahima. 2006. Keragaman Genetik di Indonesia berdasarkan Penanda Molekuler Genom Kloroplas dan Genom Inti. Disertasi. Bogor. Sekolah Pascasarjana, Institut Pertanian Bogor.

Bantacut, T. 2012. Pengembangan Agroindustri Pangan Berbasis Komoditas Lokal Untuk Kemandirian Dan Kedaulatan Pangan. Development of Local
Commodity Based Agroindustry to Retain Food Independence and Sovereignty. Departemen Teknologi Industri Pertanian Fakultas Teknologi Pertanian, Institut Pertanian Bogor.

Fitter. A.H. dan R.K.M. Hay. 1992. Fisiologi Lingkungan Tanaman. Gadjah Mada University Press. Yogyakarta.

Flach, M. 1977. The Sago Palm and its Yield Potential. First Internaasional Sago Symposium in Serawak. Univ. of Malaya Press - Kuala Lumpur.

Hardjowigeno, S. 1987. Ilmu Tanah. Meltron Putra. Jakarta.

Harsanto, P.B. 1985. Budidaya dan Pengolahan Sagu. Penerbit Kanisius, Yogyakarta.

Jong, F.S. dan A. Widjono. 2007. Potensi Besar Pertanian Indonesia, Iptek Tanaman Pangan Vol. 2 No. 1. Laman: www.puslittan.bogor.net, diakses tgl 13 Februari 2014.

Krebs, C.J. 1989. Ecological Methodology. Harper Collins Publisher, Inc. New York.

Ludwig. J.A. dan J.F. Reynold. 1988. Statistical Ecology. John Wiley and Sons; New York.

Poedjirahajoe, E. 2009. Metodologi Penelitian dan Filsafat Ilmu. UGM. Yogyakarta.

Polnaya, F.J., Haryadi, D.W. Marseno, and M.N. Cahyanto. 2012. Preparation and properties of phosphorylated of sago starches. Sago Palm 20: 311.

Sugiyono. 2005. Statistika untuk Penelitian. Cetakan Keduabelas. Bandung: CV. Alfabeta.

Wahid, A.S. 1988. Prospek pengembangan sagu di Indonesia. Jurnal Litbang Pertanian 7. 